\title{
Formulation and in vitro evaluation of fast dissolving tablets of metoprolol tartrate
}

\author{
Mangesh Machhindranath Satpute*, Nagesh Shivaji Tour \\ Department of Pharmaceutics, K. T. Patil College of Pharmacy, India
}

\begin{abstract}
The demand for fast dissolving tablets has been growing during the last decade, especially for elderly and children who have swallowing difficulties. In the present work, fast dissolving tablets of metoprolol tartrate, were prepared using sodium starch glycolate, sodium croscarmellose and crospovidone as superdisintegrants, by the direct compression method. The tablets prepared were evaluated for various parameters including weight variation, hardness, friability, in vitro dispersion time, drug-polymer interaction, drug content water absorption ratio, wetting time, in vitro drug release, FTIR and DSC studies. The tablets prepared by the direct compression method had a weight variation in the range of $145 \mathrm{mg}$ to $152 \mathrm{mg}$, which is below $\pm 7.5 \%$, a hardness of $3.6 \mathrm{~kg} / \mathrm{cm}^{2}$ to $4.5 \mathrm{~kg} / \mathrm{cm}^{2}$, percentage friability of $0.46 \%$ to $0.73 \%$, in vitro dispersion time of $18 \mathrm{~s}$ to $125 \mathrm{~s}$, drug content uniformity of between $98.12 \%$ and $100.03 \%$, a water absorption ratio of $67 \%$ to $87 \%$, wetting time of $32 \mathrm{sec}$. to $64 \mathrm{sec}$., and an in vitro drug release of $53.92 \%-98.82 \%$ within 15 min. The IR spectral analysis and DSC study showed no drug interaction with formulation additives of the tablet, and the formulations indicated no significant changes in hardness, friability, drug content or in vitro drug release. Fast dissolving tablets of metoprolol tartrate have enhanced dissolution and will lead to improved bioavailability and more effective therapy.
\end{abstract}

Uniterms: Fast dissolving tablets/in vitro evaluation. Fast dissolving tablets/formulation. Metoprolol tartrate/fast dissolving tablets/formulation. Metoprolol tartrate/in vitro evaluation. Sodium croscarmellose. Sodium starch glycolate. Crospovidone. In vitro dispersion time/tablets evaluation.

A exigência por comprimidos de dissolução rápida aumentou durante a última década, especialmente para idosos e crianças, com dificuldades de deglutição . No presente trabalho prepararam-se, pelo método de compressão direta, comprimidos de tartarato de metoprolol de rápida dissolução, utilizando glicolato sódico de amido, croscarmellose sódica e crospovidona como superdisintegrantes. Os comprimidos preparados foram avaliados em relação a diferentes parâmetros, como variação de peso, dureza, friabilidade, tempo de dispersão in vitro, interação fármaco-polímero, taxa de absorção de água pelo fármaco, tempo de umedecimento, liberação do fármaco in vitro,, FTIR e estudos de DSC. Os comprimidos preparados por compressão direta apresentaram variação de peso de $145 \mathrm{mg}$ a $152 \mathrm{mg}$, abaixo de $\pm 7,5 \%$, dureza de $3,6 \mathrm{~kg} / \mathrm{cm}^{2}$ a $4,5 \mathrm{~kg} / \mathrm{cm}^{2}$, porcentagem de friabilidade de $0,46 \%$ a $0,73 \%$, tempo de dispersão in vitro de $18 \mathrm{~s} \mathrm{a} 125 \mathrm{~s}$, uniformidade de conteúdo de fármaco entre $98,12 \% \mathrm{e}$ $100,03 \%$, taxa de absorção de água de $67 \%$ a $87 \%$, tempo de umidificaçãode $32 \mathrm{~s}$ a 64 s liberação do fármaco in vitro entre 53,92\% e 98,82\%, em 15 min. A análise no IV e de DSC mostrou que não houve interação de fármacos com os aditivos de formulação do comprimido e as formulações indicaram que não houve mudança significativa na dureza, friabilidade, $s$ uniformidade de conteúdo de fármaco e na liberação do fármaco in vitro. Os comprimidos de liberação rápida apresentaram aumento na dissolução de tartarato metoprolol e conduzem à melhoria dabiodisponibilidade e à terapia eficaz.

Unitermos: Comprimidos de dissolução rápida/avaliação in vitro. Comprimidos de dissolução rápida/ formulação. Tartarato de metoprolol/comprimidos de dissolução rápida/formulação. Tartarato de metoprolol/ avaliação in vitro. Croscarmelose sódica. Glicolato sódico de amido. Crospovidone. Tempo de dispersão in vitro/avaliação de comprimidos.

\footnotetext{
*Correspondence: Mangesh M. Satpute. Department of Pharmaceutics, K. T. Patil College of Pharmacy, 413501 - Osmanabad - Maharashtra, India. E-mail: mangesh9787@gmail.com
} 


\section{INTRODUCTION}

Elderly people, children and patients sometimes have difficulties swallowing tablets or hard gelatin capsules. In addition, such difficulties apply not only to patients but also to active working people who have no access to water. These problems can be resolved by means of tablets which disintegrate rapidly in the mouth (Sugimoto et al., 2006).

Recently, fast dissolving tablets (FDTs) have become increasingly popular around the world. On the basis of requests from patients to enhance their quality of life (QOL), new types of FDTs have been developed and then released globally by many pharmaceutical companies (Okuda et al., 2011). These tablets display a fast and spontaneous de-aggregation in the mouth, soon after coming into contact with saliva, dissolving the active ingredient and allowing absorption through all possible membranes it comes into contact with during deglutition (Puttewar et al., 2010).

Fast dissolving tablets are useful for patients with difficulties swallowing conventional tablets, for example pediatric patients and patients under chemotherapy treatment. Patients on chemotherapy treatment may have nausea which is so intense that it complicates the administration of conventional tablets; typically this has been done with water, especially in those with tumors of the mouth and esophagus. Nausea and emesis continue to cause significant problems for patients with cancer receiving highly or moderately emetogenic chemotherapy (Armando et al., 2009). Direct absorption through the oral mucosa allows drugs to achieve systemic circulation, bypassing the gastrointestinal tract and the first-pass metabolism of the liver. To allow fast dissolving of dosage forms in the mouth, these delivery systems comprise either very porous and soft-moulded matrices or compression into tablets with very low compression force (Lai et al., 2011).

However, as a result of rapid FDT disintegration, the active substance comes into contact with the taste buds and the need for a pleasant taste becomes a key aspect for patient palatability. Thus, the taste-masking of bitter active substances is a critical hurdle to overcome for the successful development of FDT formulations. In general, oral administration of bitter active substances through FDT formulations should provide an improved degree of palatability and increased patient compliance with dissolving/disintegrating tablets that include sweeteners and flavors. Nevertheless, these additives were not a sufficient means for complete taste-masking. Recent advances in technology have presented viable dosage alternatives to taste-mask bitter drugs. Several approaches have been reported which involve complexation, freezedrying, microencapsulation, fluidized-bed coating and supercritical fluids for taste-masking purposes (Gryczkc et al., 2011).

\section{MATERIAL AND METHODS}

Metoprolol tartrate was obtained from Cipla Pharma, Mumbai, India. Crospovidone, sodium starch glycolate and sodium croscarmellose were also obtained from Cipla Pharma Mumbai, India. Microcrystalline cellulose and mannitol were obtained from Ajantha Pharma, Aurangabad. All other chemicals of analytical grade were purchased from commercial sources.

\section{Preparation of fast dissolving tablets by direct compression method}

Fast dissolving tablets of metoprolol tartrate were prepared by direct compression. All the ingredients (except granular directly compressible excipients) were passed through \# 60-mesh separately. The ingredients were then weighed and mixed in geometrical order and compressed into tablets of $150 \mathrm{mg}$ using $6 \mathrm{~mm}$ round concave punches on an 8-station rotary tablet machine (Karnavati) (Shirsand et al., 2010) (Table I).

\section{Evaluation of metoprolol tartrate fast dissolving tablets}

Evaluation of pre-compression parameters of powder

- $\quad$ Preformulation study

- $\quad$ Angle of repose $(\theta)$

The angle of repose was determined by using the funnel method. The accurately weighed blend was taken in a funnel. The height of the funnel was adjusted in such a way that the tip of funnel just touched the apex of the heap and the drug-excipient blend was allowed to flow through the funnel freely to the surface. The diameter of the powder cone was measured and angle of repose calculated using the following equation.

$$
\operatorname{Tan} \theta=\mathrm{h} / \mathrm{r}
$$

Different ranges of flowability in terms of angle of repose (Table II) are given below (Bikshapathi et al., 2011).

\section{- $\quad$ Bulk density $(\mathrm{Pb})$}

Apparent bulk density $(\mathrm{Pb})$ was determined by pouring the blend into a graduated cylinder. The bulk 
TABLE I - Formulation of metoprolol tartrate fast dissolving tablets prepared by direct compression method

\begin{tabular}{|c|c|c|c|c|c|c|c|c|c|}
\hline \multirow{2}{*}{ Ingredient(mg) } & \multicolumn{9}{|c|}{ Formulation code } \\
\hline & MT1 & MT2 & MT3 & MT4 & MT5 & MT6 & MT7 & MT8 & MT9 \\
\hline Metoprolol tartrate & 25 & 25 & 25 & 25 & 25 & 25 & 25 & 25 & 25 \\
\hline Sodium croscarmellose & 05 & 10 & 15 & & & & & & \\
\hline Crospovidone & & & & 05 & 10 & 15 & & & \\
\hline Sodium starch glycolate & & & & & & & 5 & 10 & 15 \\
\hline Aspartame & 10 & 10 & 10 & 10 & 10 & 10 & 10 & 10 & 10 \\
\hline Mg stearate & 02 & 02 & 02 & 02 & 02 & 02 & 02 & 02 & 02 \\
\hline Aerosil & 03 & 03 & 03 & 03 & 03 & 03 & 03 & 03 & 03 \\
\hline Methyl cellulose & 03 & 03 & 03 & 03 & 03 & 03 & 03 & 03 & 03 \\
\hline MCC(Avicel PH-102) & 37 & 37 & 37 & 37 & 37 & 37 & 37 & 37 & 37 \\
\hline D- Mannitol & 65 & 60 & 55 & 65 & 60 & 55 & 65 & 60 & 55 \\
\hline Total & 150 & 150 & 150 & 150 & 150 & 150 & 150 & 150 & 150 \\
\hline
\end{tabular}

Formulation code: MT1 - Formulation containing 3.3\% sodium croscarmellose; MT 2 - Formulation containing $6.6 \%$ sodium croscarmellose; MT 3 - Formulation containing 10\% sodium croscarmellose; MT 4 - Formulation containing 3.3\% crospovidone; MT 5 - Formulation containing 6.6\% crospovidone; MT 6 - Formulation containing 10\% crospovidone; MT 7 - Formulation containing 3.3\% sodium starch glycolate; MT 8 - Formulation containing 6.6\% sodium starch glycolate; MT 9 - Formulation containing $10 \%$ sodium starch glycolate.

TABLE II - Relationship between angle of repose $(\theta)$ and flow properties

\begin{tabular}{cc}
\hline Angle of repose $(\theta)$ (degrees) & Flow \\
\hline$<25$ & Excellent \\
$25-30$ & Good \\
$30-40$ & Passable \\
$>40$ & Very poor \\
\hline
\end{tabular}

volume $(\mathrm{Vb})$ and weight of powder $(\mathrm{M})$ was determined. The bulk density was calculated using the formula (ShahV et al., 2011).

$$
\mathrm{Pb}=\mathrm{M} / \mathrm{Vb}
$$

- $\quad$ Tapped density $(\mathrm{Pt})$

The measuring cylinder containing a known mass of blend was tapped for a fixed time. The minimum volume $(\mathrm{Vt})$ occupied in the cylinder and the weight $(\mathrm{M})$ of the blend was measured. The tapped density (pt) was calculated using the formula (Suresh et al., 2011).

$$
\mathrm{Pt}=\mathrm{M} / \mathrm{Vt}
$$

- Hausner's ratio

Hausners's ratio is the ratio of tapped density to bulk density. The lower the value of Hausner's ratio the better the flow property. The ratio is calculated by the following formula

$$
\text { Hausners's ratio }=\frac{\text { Tapped density }}{\text { Bulk density }}
$$

Lower Hausner ratios $(<1.25)$ indicate better flow properties than higher ratios $(>1.25)$ (Sayeed et al., 2011).

- $\quad$ Carr's compressibility index

The percentage compressibility (Carr's index) was calculated as 100 times the ratio of the difference between tapped density and bulk density to tapped density (Sayeed et al., 2011). (Table III).

It is expressed in percentage and calculated by the following formula

$$
\text { Carr's index }=100 \times \frac{\text { Tapped density }- \text { Bulk density }}{\text { Tapped density }}
$$

TABLE III - Grading of the powders for their flow properties according to Carr's index

\begin{tabular}{cc}
\hline Consolidation index (Carr's \%) & Flow \\
\hline $5-15$ & Excellent \\
$12-16$ & Good \\
$18-21$ & Fair to passable \\
$23-35$ & Poor \\
$33-38$ & Very poor \\
$>40$ & Very very poor \\
\hline
\end{tabular}




\section{Drug polymer interaction studies}

- FTIR study

The study was carried out to determine the molecular structure, serving as an identification test to ascertain the purity of the molecule. IR spectroscopy was obtained by a FTIR spectrophotometer (H400-84100, Shimadzu, Japan) using $\mathrm{KBr}$ pellets. The scanning range used was 4400 to $400 \mathrm{~cm}^{-1}$ at a scan period of $1 \mathrm{~min}$. Spectra of pure drug and the blend are shown in Figures 1 and 2. There is no change in the shape of the peak or shift of the peak, hence the drug and excipients are compatible ( Prameela et al., 2010).

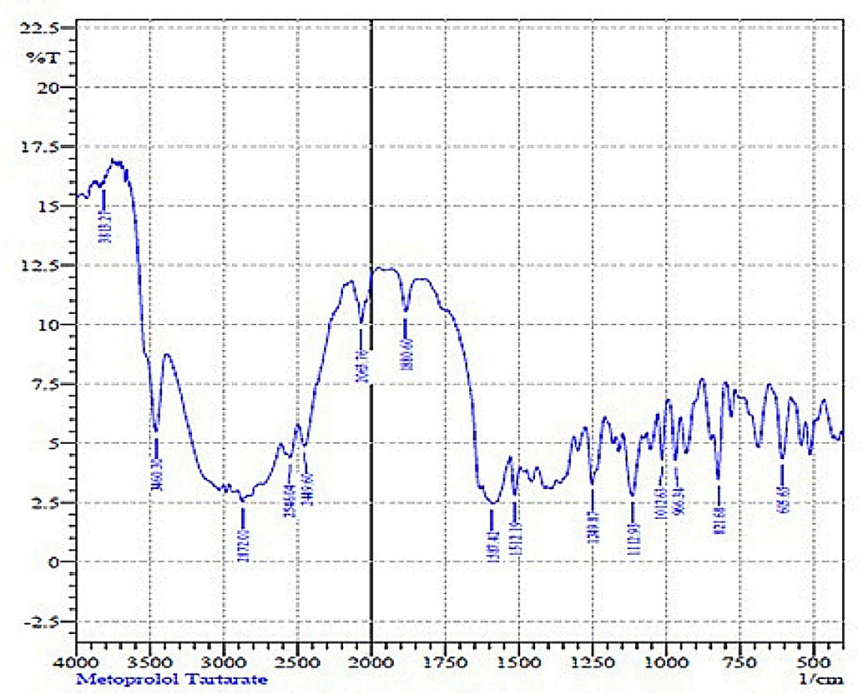

FIGURE 1 - FT-IR spectrum of metoprolol tartrate.

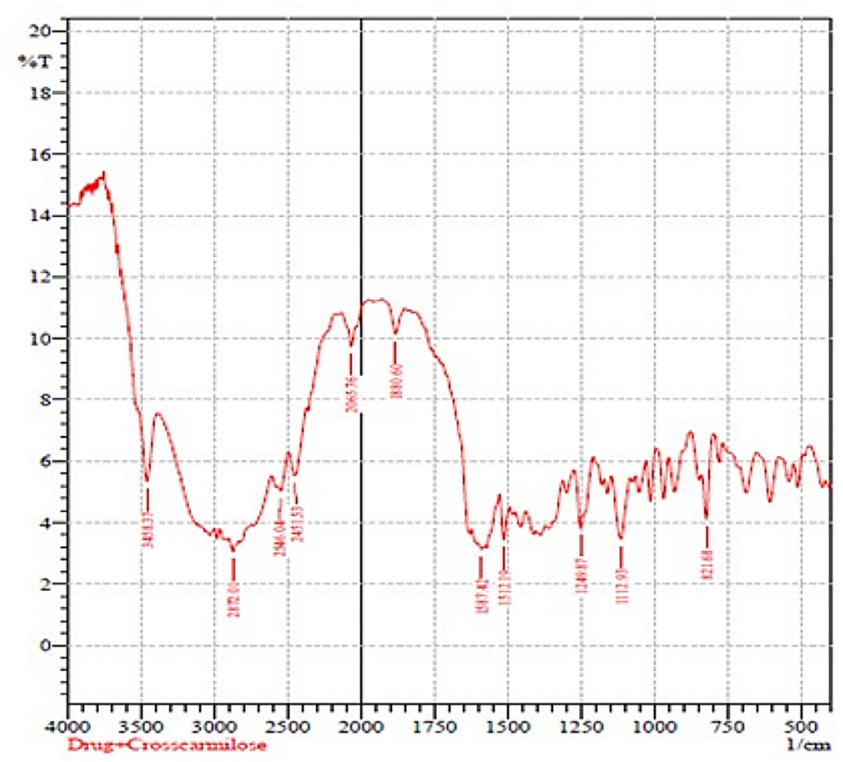

FIGURE 2 - FT-IR spectrum of metoprolol tartrate with sodium croscarmellose.
- Differential scanning calorimetry (DSC) Study

DSC analysis of pure drug, and of the optimized formulation was performed on a Shimadzu DSC 60 thermal analyser at the heating flow rates of $5^{\circ} \mathrm{C}$ per min between $50-300{ }^{\circ} \mathrm{C}$ under static air using aluminium pans (Nayak et al., 2011).

\section{Evaluation of post-compression parameters of tablets}

\section{- Hardness test}

The hardness of a tablet is indicative of its tensile strength and is measured in terms of load/pressure required to crush it when placed on its edge. A number of handy hardness testers such as the Mosanto type or Pfizer type are currently in use. Hardness of about 5 $\mathrm{kg}$ is considered to be a minimum for uncoated tablets for mechanical stability. The hardness is a function of physical properties of granules such as hardness and deformation under load, binders and above all the compressional force. The hardness has an influence on disintegration and dissolution times and is, as such, a factor that may affect bioavailabilities (Puttewar et al., 2010).

\section{- $\quad$ Friability test}

Friability of the tablets was determined using a Roche friabilator. This device subjects the tablets to the combined effect of abrasions and shock in a plastic chamber revolving at $25 \mathrm{rpm}$, dropping the tablets from a height of 6 inches on each revolution. A preweighed sample of tablets was placed in the friabilator and subjected to 100 revolutions. Tablets were de-dusted using a soft muslin cloth and reweighed.

The friability $(\mathrm{F} \%)$ is given by the formula

$$
\mathrm{f}=\frac{\left(\mathrm{W}_{0} \text { initial }\right)-(\text { Wfinal })}{\left(\mathrm{W}_{0} \text { initial }\right)} \times 100
$$

Where, $\mathrm{W}_{0}$ is weight of the tablets before the test and $\mathrm{W}$ is the weight of the tablets after the test (Mehta et al., 2009).

\section{- Weight variation test}

Twenty tablets were selected randomly and average weight was determined. Subsequently, individual tablets were weighed and compared with average weight. If the comparison variation lies within the I.P limits, it passes the weight variation test (Chandira et al., 2010).

- Water absorption

A piece of tissue paper folded twice was placed in 
a small Petri dish containing $6 \mathrm{ml}$ of water. A tablet was placed on the paper and the time required for complete wetting was measured. The wetted tablet was then weighed. Water absorption ratio is indicated by $\mathrm{R}$, which is calculated by using the equation below (Chandira et al., 2010).

$$
\mathrm{R}=10 \times \frac{\mathrm{Wa}-\mathrm{Wb}}{\mathrm{Wb}}
$$

- Uniformity of thickness

Thickness can be measured using a simple procedure. A total of 5 tablets were taken and their thicknesses measured using Vernier calipers. The thickness was measured by placing the tablet between the two arms of the Vernier calipers (Parmar et al., 2009).

- $\quad$ Drug content uniformity

The formulated tablets were also analyzed for the drug uniformity contents as per the Indian Pharmacopoeia. A total of 20 tablets were taken, weighed and ground. An amount of this powder equivalent to $5 \mathrm{mg}$ of the drug was accurately weighed, suitably diluted and analyzed on a double-beam UV spectrophotometer (Jasco- 630V) at $221.70 \mathrm{~nm}$. (Bagul et al., 2010).

- Wetting time

A piece of double-folded tissue paper was placed in a petri plate (internal diameter $6.5 \mathrm{~cm}$ ) containing $6 \mathrm{ml}$ of water. The tablet was placed on the paper and the time for complete wetting of the tablet was measured in seconds. The method was slightly modified by maintaining water at $37{ }^{\circ} \mathrm{C}$ (Figure 3) (Margret et al., 2010).

- In vitro disintegration time

The disintegration time was measured using disintegration test apparatus. One tablet was placed in each tube of the basket. This basket was immersed in a water bath at $37+20{ }^{\circ} \mathrm{C}$. The time required for complete disintegration was recorded with standard deviation (Chacko et al., 2010) (Table VI)

\section{- In vitro dissolution studies}

The in vitro dissolution study was performed using an USP dissolution apparatus Type 2 (Paddle type) at $100 \mathrm{rpm}$ using $900 \mathrm{ml}$ phosphate buffer $\mathrm{pH} 6.8$ as the dissolution medium at $37 \pm 0.5^{\circ} \mathrm{C}$. Aliquots of dissolution medium were withdrawn and the absorbances of filtered solutions determined by a UV Spectrophotometer at $221.70 \mathrm{~nm}$. Six trials were performed for each batch and average percentage drug release with standard deviation was calculated and recorded (Chacko et al., 2010).

\section{RESULTS AND DISCUSSION}

Fast dissolving tablets of metoprolol tartrate were prepared by a method employing crospovidone, sodium starch glycolate and sodium croscarmellose as super-disintegrants at different ratios. A total of nine formulations were designed. The flow properties of the powder mixture are important for the uniformity of mass of the tablets; the flow of the powder mixture was analyzed before compression to tablets. Low Hausner's ratio $(\leq 1.14)$, compressibility index $(\leq 15)$ and angle of repose $(\leq 28.04)$ values indicated fairly good flowability of the powder mixture (Table IV).

As the tablet powder mixture was free flowing, tablets produced were of uniform weight with acceptable weight variation in the range from $145 \mathrm{mg}$ to $152 \mathrm{mg}$ due to uniform die fill. Hardness $\left(3.6 \mathrm{~kg} / \mathrm{cm}^{2}-4.5 \mathrm{~kg} / \mathrm{cm}^{2}\right)$ and friability loss $(0.46 \%-0.73 \%)$ indicated that tablets had good mechanical resistance. Drug content was found to be high ( $\geq 98.12 \%$ ) in all the tablet formulations. Water absorption ratio and wetting time, which are important criteria for understanding the capacity of disintegrants to swell in the presence of a small amount of water, were

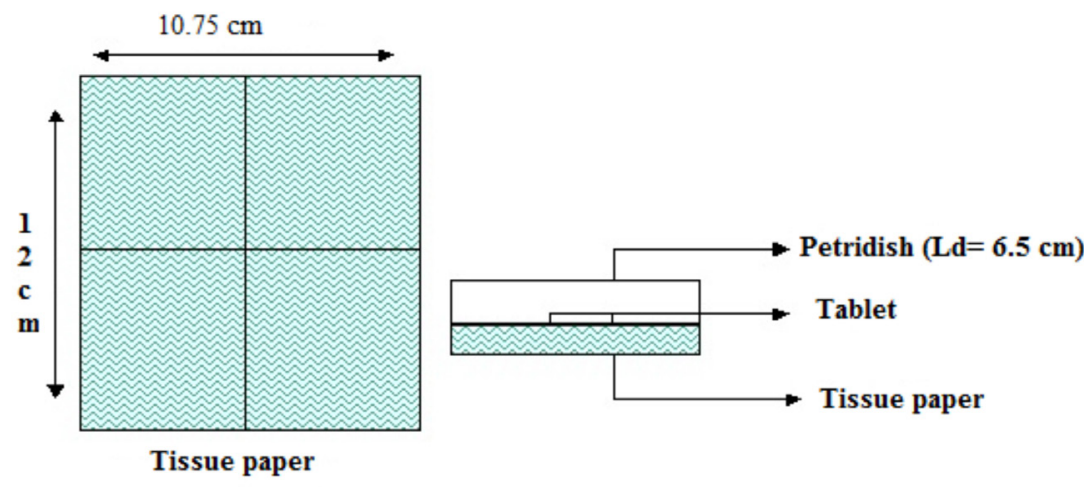

FIGURE 3 - Wetting time determination. 
TABLE IV - Pre-compression results of direct compression method

\begin{tabular}{lccccc}
\hline Formulation code & $\begin{array}{c}\text { Bulk density } \\
(\mathrm{g} / \mathrm{cc})\end{array}$ & $\begin{array}{c}\text { Tapped density } \\
(\mathrm{g} / \mathrm{cc})\end{array}$ & $\begin{array}{c}\text { Angle of repose } \\
(\text { degrees })\end{array}$ & $\begin{array}{c}\text { Carr's index } \\
(\%)\end{array}$ & Hausner's Ratio \\
\hline $\mathrm{MT}_{1}$ & 0.54 & 0.65 & 28.04 & 16 & 1.20 \\
$\mathrm{MT}_{2}$ & 0.52 & 0.63 & 30.14 & 17 & 1.21 \\
$\mathrm{MT}_{3}$ & 0.51 & 0.62 & 28.85 & 17 & 1.21 \\
$\mathrm{MT}_{4}$ & 0.55 & 0.65 & 28.26 & 15 & 1.14 \\
$\mathrm{MT}_{5}$ & 0.50 & 0.63 & 28.43 & 20 & 1.26 \\
$\mathrm{MT}_{6}$ & 0.53 & 0.64 & 30.01 & 17 & 1.20 \\
$\mathrm{MT}_{7}$ & 0.53 & 0.63 & 30.02 & 15 & 1.20 \\
$\mathrm{MT}_{8}$ & 0.51 & 0.62 & 28.87 & 17 & 1.21 \\
$\mathrm{MT}_{9}$ & 0.52 & 0.65 & 27.52 & 18 & 1.21 \\
\hline
\end{tabular}

Formulation code: MT 1 - Formulation containing 3.3\% sodium sodium croscarmellose; MT 2 - Formulation containing $6.6 \%$ sodium sodium croscarmellose; MT 3 - Formulation containing 10\% sodium croscarmellose croscarmellose; MT 4 - Formulation containing $3.3 \%$ crospovidone; MT 5 - Formulation containing 6.6\% crospovidone; MT 6 - Formulation containing 10\% crospovidone; MT 7 - Formulation containing 3.3\% sodium starch glycolate; MT 8 - Formulation containing $6.6 \%$ sodium starch glycolate; MT 9 Formulation containing $10 \%$ sodium starch glycolate.

found to be in the range of $67.32 \%-87.91 \%$ and $28 \mathrm{sec}-$ $57 \mathrm{sec}$, respectively (Tables V and VI).

The most important parameter that needs to be optimized in the development of fast disintegrating tablets is the disintegration time of tablets. In the present study, it was observed that the disintegration time of the tablets had no effect with increasing level of crospovidone. The faster disintegration of crospovidone tablets may be attributed to its rapid capillary activity and pronounced hydration with low capacity for gel formation. Thus, these results suggest that disintegration times can be reduced by using a wicking type disintegrant (crospovidone). Thus, wetting times of tablets with crospovidone were found to be less than those with

TABLE V - Post-compressional parameters for direct compression method

\begin{tabular}{|c|c|c|c|c|}
\hline Formulation Code & $\begin{array}{c}\text { Hardness* }\left(\mathrm{kg} / \mathrm{cm}^{2}\right) \\
\text { Mean } \pm \mathrm{SD}\end{array}$ & Friability (\%) & $\begin{array}{l}\text { Thickness* }(\mathrm{mm}) \\
\text { Mean } \pm \text { SD }\end{array}$ & $\begin{array}{l}\text { Weight variation }(\mathrm{mg}) \\
\quad \text { Mean } \pm \text { SD }\end{array}$ \\
\hline $\mathbf{M T}_{1}$ & $4.3 \pm 0.11$ & 0.46 & $4.3 \pm 0.05$ & $146 \pm 1.37$ \\
\hline $\mathrm{MT}_{2}$ & $3.7 \pm 0.15$ & 0.66 & $4.2 \pm 0.07$ & $145 \pm 1.35$ \\
\hline $\mathrm{MT}_{3}$ & $3.5 \pm 0.15$ & 0.70 & $4.6 \pm 0.10$ & $149 \pm 1.40$ \\
\hline $\mathbf{M T}_{4}$ & $4.3 \pm 0.19$ & 0.60 & $4.4 \pm 0.09$ & $148 \pm 1.34$ \\
\hline $\mathbf{M T}_{5}$ & $4.1 \pm 0.14$ & 0.46 & $4.1 \pm 0.20$ & $149 \pm 1.31$ \\
\hline $\mathrm{MT}_{6}$ & $4.4 \pm 0.23$ & 0.56 & $4.6 \pm 0.10$ & $148 \pm 1.40$ \\
\hline $\mathbf{M T}_{7}$ & $4.5 \pm 0.07$ & 0.73 & $4.8 \pm 0.10$ & $150 \pm 1.24$ \\
\hline $\mathbf{M T}_{8}$ & $4.2 \pm 0.10$ & 0.53 & $4.5 \pm 0.11$ & $152 \pm 1.35$ \\
\hline $\mathrm{MT}_{9}$ & $3.6 \pm 0.19$ & 0.66 & $4.6 \pm 0.05$ & $147 \pm 1.36$ \\
\hline
\end{tabular}

Values expressed as Mean $\pm \operatorname{SD}(n=3)$.

Formulation code: MT 1 - Formulation containing 3.3\% sodium sodium croscarmellose; MT 2 - Formulation containing $6.6 \%$ sodium croscarmellose roscarmellose; MT 3 - Formulation containing 10\% sodium sodium croscarmellose; MT 4 - Formulation containing $3.3 \%$ crospovidone; MT 5 - Formulation containing $6.6 \%$ crospovidone; MT 6 - Formulation containing $10 \%$ crospovidone; MT 7 - Formulation containing 3.3\% sodium starch glycolate; MT 8 - Formulation containing 6.6\% sodium starch glycolate; MT 9 Formulation containing $10 \%$ sodium starch glycolate. 
TABLE VI - Post-compressional parameters for direct compression method

\begin{tabular}{|c|c|c|c|c|}
\hline Formulation Code & $\begin{array}{l}\text { In vitro dispersion time* } \\
(\mathrm{sec})\end{array}$ & Wetting time* $(\mathrm{sec})$ & Water absorption ratio* & Drug Content* (\%) \\
\hline $\mathbf{M T}_{1}$ & $35 \pm 1.27$ & $49 \pm 1.36$ & $84 \pm 1.05$ & $99.18 \pm 0.72$ \\
\hline $\mathbf{M T}_{2}$ & $92 \pm 1.25$ & $46 \pm 1.18$ & $74 \pm 0.80$ & $99.81 \pm 1.07$ \\
\hline $\mathbf{M T}_{3}$ & $62 \pm 1.30$ & $42 \pm 1.22$ & $67 \pm 1.06$ & $99.54 \pm 0.50$ \\
\hline $\mathrm{MT}_{4}$ & $22 \pm 1.37$ & $32 \pm 1.29$ & $82 \pm 1.28$ & $98.12 \pm 0.73$ \\
\hline $\mathbf{M T}_{5}$ & $18 \pm 1.35$ & $28 \pm 1.27$ & $87 \pm 1.36$ & $99.30 \pm 0.87$ \\
\hline $\mathrm{MT}_{6}$ & $25 \pm 1.36$ & $36 \pm 1.37$ & $81 \pm 1.38$ & $99.23 \pm 0.90$ \\
\hline $\mathbf{M T}_{7}$ & $99 \pm 1.31$ & $57 \pm 1.32$ & $71 \pm 1.34$ & $100.03 \pm 1.07$ \\
\hline $\mathbf{M T}_{8}$ & $116 \pm 1.35$ & $64 \pm 1.36$ & $75 \pm 1.44$ & $99.63 \pm 0.39$ \\
\hline $\mathbf{M T}_{9}$ & $125 \pm 1.40$ & $48 \pm 1.40$ & $74 \pm 1.31$ & $99.50 \pm 0.77$ \\
\hline
\end{tabular}

Values expressed as Mean \pm SD $(n=3)$.

Formulation code: MT 1 - Formulation containing 3.3\% sodium sodium croscarmellose; MT 2 - Formulation containing 6.6\% sodium sodium croscarmellose; MT 3 - Formulation containing 10\% sodium sodium croscarmellose; MT 4 - Formulation containing $3.3 \%$ crospovidone; MT 5 - Formulation containing 6.6\% crospovidone; MT 6 - Formulation containing 10\% crospovidone; MT 7 - Formulation containing 3.3\% sodium starch glycolate; MT 8 - Formulation containing $6.6 \%$ sodium starch glycolate; MT 9 Formulation containing $10 \%$ sodium starch glycolate.

sodium starch glycolate or sodium croscarmellose. These results are consistent with disintegration test results. IR shows the drug interaction study, indicating that the drug is compatible with all the excipients (Figures 4 and 5).

The DSC shows that when the drug metoprolol tartrate was taken to study its properties at higher temperature, it exhibited a melting peak at $126.69^{\circ} \mathrm{C}$ with very little variation compared with the literature-reported temperature. This is probably due to error in experimental

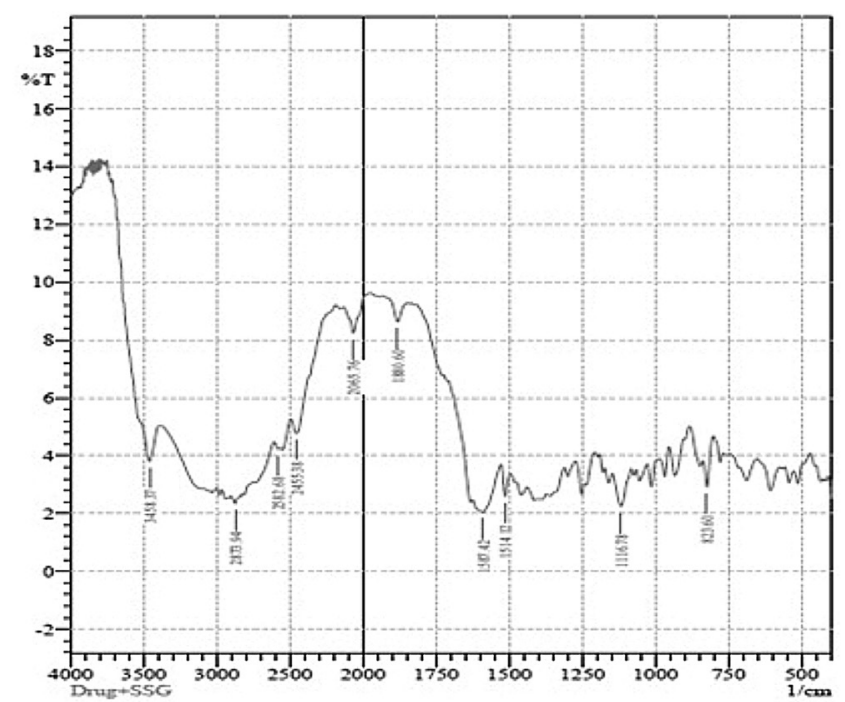

FIGURE 4 - FT-IR spectrum of metoprolol tartrate with sodium starch glycolate. determination. The DSC of the optimized formulation showed a melting peak at $120.19{ }^{\circ} \mathrm{C}$. DSC studies of all formulations indicated that no chemical constituent produced any reaction products (Figure 6 and 7).

In vitro drug release studies were carried out in phosphate buffer pH 6.8 and the dissolution profile is depicted in Table VII and Figures $8-10$. The drug release from the optimized batch (MT5) was $98.82 \%$ at $15 \mathrm{~min}$.

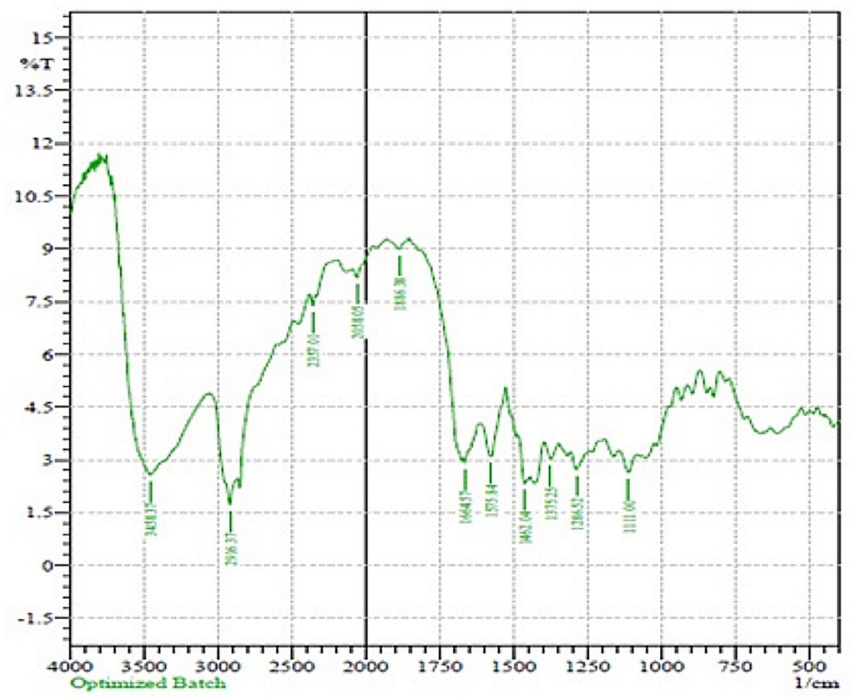

FIGURE 5 - FT-IR spectrum of metoprolol tartrate with optimized FDT formulation. 


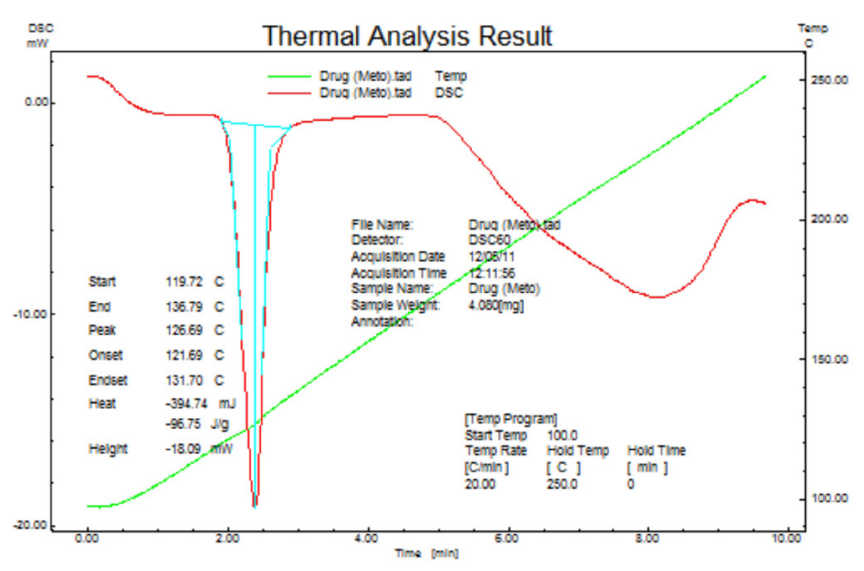

FIGURE 6 - DSC analysis of metoprolol tartrate.

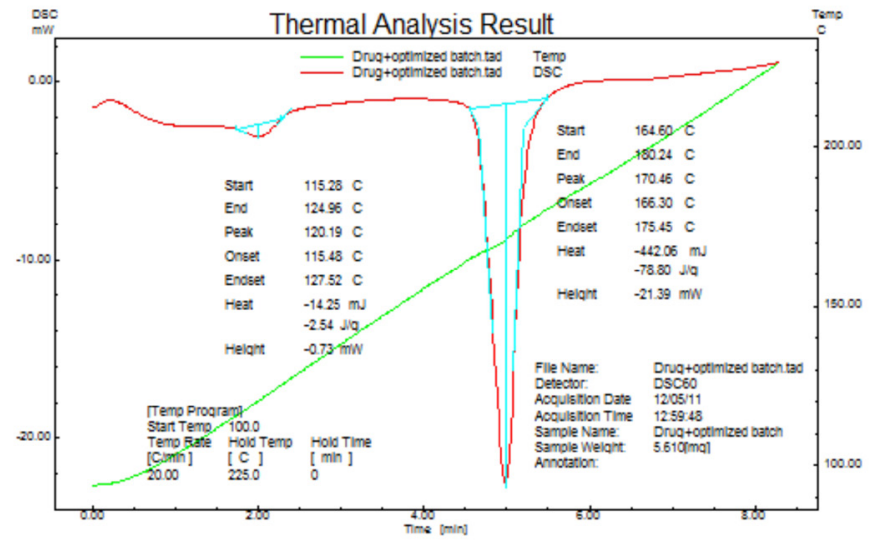

FIGURE 7 - DSC analysis of metoprolol tartrate with optimized FDT formulation.

TABLE VII - Dissolution of metoprolol tartrate in phosphate buffer pH 6.8 from tablets of MT1 to MT9

\begin{tabular}{lccccccccc}
\hline \multirow{2}{*}{ Time (min) } & \multicolumn{10}{c}{ Cumulative \% Drug release } \\
\cline { 2 - 9 } & MT1 & MT2 & MT3 & MT4 & MT5 & MT6 & MT7 & MT8 & MT9 \\
\hline 00 & 0.00 & 0.00 & 0.00 & 0.00 & 0.00 & 0.00 & 0.00 & 0.00 & 0.00 \\
03 & 50.61 & 52.34 & 49.35 & 52.25 & 53.92 & 51.10 & 47.63 & 49.35 & 45.48 \\
06 & 64.18 & 65.35 & 63.40 & 66.49 & 68.78 & 64.92 & 59.95 & 62.45 & 58.56 \\
09 & 75.64 & 76.80 & 75.90 & 77.95 & 79.10 & 75.98 & 69.96 & 72.30 & 68.89 \\
12 & 88.54 & 89.72 & 87.45 & 92.68 & 93.90 & 90.10 & 75.25 & 78.23 & 73.98 \\
15 & 93.73 & 94.20 & 91.10 & 97.97 & 98.82 & 95.52 & 82.76 & 84.88 & 80.54 \\
18 & 96.51 & 98.45 & 95.28 & & & & 88.34 & 89.56 & 87.18 \\
21 & & & & & & & 93.06 & 94.12 & 92.18 \\
24 & & & & & & & 97.24 & 98.41 & 95.13 \\
\hline
\end{tabular}

Formulation code: MT 1 - Formulation containing 3.3\% sodium croscarmellose; MT 2 - Formulation containing $6.6 \%$ sodium sodium croscarmellose; MT 3 - Formulation containing 10\% sodium sodium croscarmellose; MT 4 - Formulation containing $3.3 \%$ crospovidone; MT 5 - Formulation containing 6.6\% crospovidone; MT 6 - Formulation containing 10\% crospovidone; MT 7 - Formulation containing 3.3\% sodium starch glycolate; MT 8 - Formulation containing 6.6\% sodium starch glycolate; MT 9 Formulation containing $10 \%$ sodium starch glycolate.

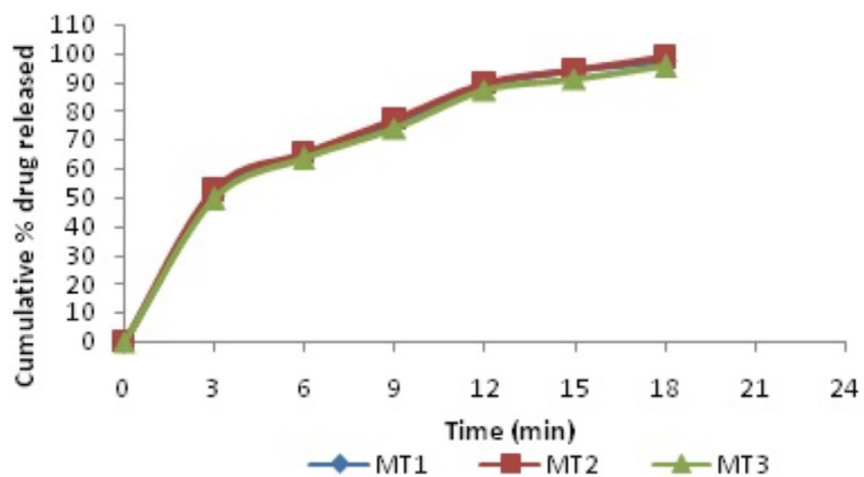

FIGURE 8 - In vitro release of metoprolol tartrate from tablets of MT1 to MT3.

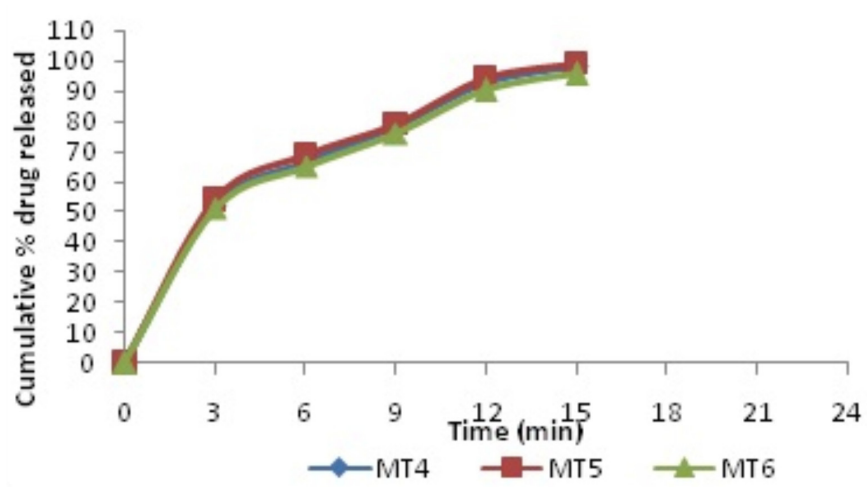

FIGURE 9 - In vitro release of metoprolol tartrate from tablets of MT4 to MT6. 


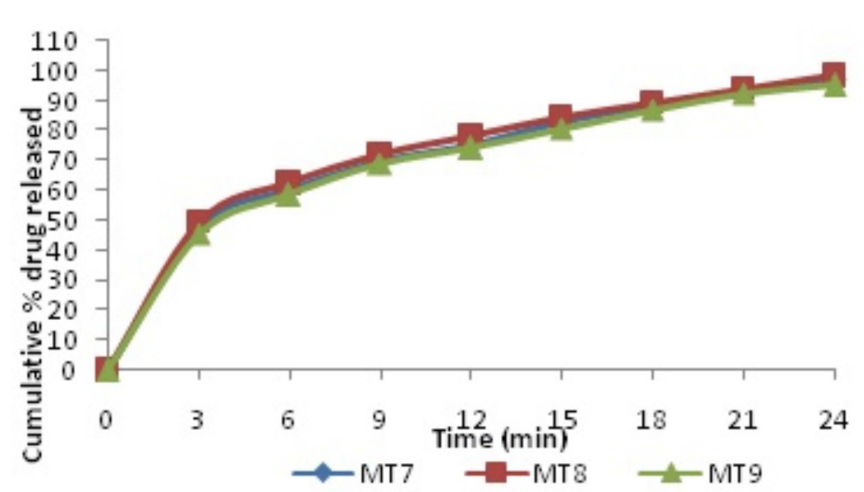

FIGURE 10 - In vitro release of metoprolol tartrate from tablets of MT7 to MT9.

\section{CONCLUSION}

In the present work, fast dissolving tablets of metoprolol tartrate were prepared by direct compression methods using superdisintegrants such as sodium starch glycolate, sodium croscarmellose and crospovidone. All the tablets of metoprolol tartrate were subjected to tests for weight variation, hardness, friability, in vitro dispersion, drug polymer interaction, drug content uniformity, water absorption ratio, wetting time, and in vitro drug release.

Based on the above studies, the following conclusions can be drawn:

- $\quad$ Tablets prepared by direct compression methods were found to be good and free from chipping and capping.

- The low values of the standard deviation of average weight of the prepared tablets indicated weight uniformity within the batches prepared.

- The hardness of the prepared tablets was found to be in the range of $3.6 \mathrm{~kg} / \mathrm{cm}^{2}$ to $4.5 \mathrm{~kg} / \mathrm{cm}^{2}$. The friability values of the prepared tablets were found to be less than $1 \%$.

- IR spectroscopic and DSC studies indicated that the drug is compatible with all the excipients.

- $\quad$ The in vitro dispersion time of metoprolol tartrate prepared by the direct compression method was found to be in the range of $18 \mathrm{sec}$. to $125 \mathrm{sec}$. fulfilling the official requirements.

- Based on the in vitro disintegration time, formulation MT5 (6.6\% crospovidone) was found to be promising and showed a dispersion time of $18 \mathrm{sec}$ and wetting time of $28 \mathrm{sec}$., facilitating faster dispersion in the mouth.

- The formulation MT5 displayed a good water absorption ratio of $87.91 \%$, indicating better and faster swelling ability of the disintegrants in the presence of a small amount of water.
- $\quad$ The drug content of tablets was uniform across all batches, ranging from $98.12 \%$ to $100.03 \%$.

- $\quad$ The drug release from the optimized batch (MT5) was about $98.82 \%$ at $15 \mathrm{~min}$.

\section{REFERENCES}

AI, F.; PINI, E.; ANGIONI, G.; MANCA, M.; PERRICI, J.; SINICO, C.; FADDA, A. Nanocrystals as tool to improve piroxicam dissolution rate in novel orally disintegrating tablets. Eur. J. Pharm. Biopharm., v.79, p.552-558, 2011.

ARMANDO, Y.; SCHRAMM, S.; SILVA, M.; KANO, E.; PORTA, V.; SERRA, C. Bioequivalence assay between orally disintegrating and conventional tablet formulations in healthy volunteers. Int. J. Pharm., v.366, p.149-153, 2009.

BAGUL, U.; GUJAR, K.; PATEL, N.; APHALE, S. Formulation and evaluation of sublimed fast melt tablets of levocetirizine dihydrochloride. Int. J. Pharm. Sci., v.2, n.2, p.76-80, 2010.

BIKSHAPATHI, D.; SAIKRISHNA, K.; KUMAR, U. Fast dissolving tablets: an update. Int. Res. J. Pharm., v.2,n.3, p.45-53, 2011.

CHACKO, A.; JOSE, S.; BABU N. Design and development of orodispersible tablets of promethazine theoclate using coprocessed superdisintegrants and subliming materials. Int. J. Innov. Pharm. Res., v.1, n.2, p.53-56, 2010.

CHANDIRA, R.; VENKATAESWARLU, B. Formulation and evaluation of mouth dissolving tablets of the etoricoxib. Pak. J. Pharm. Sci., v.23, n.2, p.178-181, 2010.

GRYCZKC, A.; SHMINKE, S.; MANIRUZZAMAN, M.; BERK, J.; DOUROUMIS, D. Development and evaluational of orally disintegrating tablets containing ibuprofen granules prepared by hot melt extrusion. Colloids Surfaces B., v.86, p.275-284, 2011.

MARGRET, R.; VENKATAESWARLU, B.; KUMUDHAVALLI M. Formulation and evaluation of mouth dissolving tablets of the etoricoxib. Pak. J. Pharm. Sci., v.23, n.2, p.178-181, 2010.

MEHTA, M.; DEEPAK, P.; GUPTA, G. Fast dissolving tablets of sertraline hydrochloride. Int. J. Chem. Tech. Res., v.1, n. 4 , p.925-930, 2009. 
NAYAK, R.; PATIL, S.; PATIL, M.; BHAT, M. Evaluation of disintegrating properties of mangifera indica gum. RGUHS J. Pharm. Sci., v.1, n.1, p.11-21, 2011.

OKUDA, Y.; IRISAWA, Y.; OKIMOTO, K.; YAMASHITA, S. Further improvement of orally disintegrating tablets using micronized ethylcellulose. Int. J. Pharm., , p.01-09, 2011.

PARMAR, R.; BARIA, A.; TANK, H.; FALDU, S. Formulation and evaluation of domperidone fast dissolving tablets. Int. J. Pharm. Tech. Res., v.1, n.3, p.483-487, 2009.

PRAMEELA, A.; ARCHANA, P.; SIVA TEJA, P.; VIKAS M. Formulation and evaluation of orodispersible metformin tablets: A Comparative study on hisapghula husk and crospovidone as superdisintegrants. Int. J. Appl. Pharm., v.2, n.3, p.15-21, 2010.

PUTTEWAR, T.; KSHIRSAGAR, M.; CHANDEWAR, A.; CHIKHALE, R. Formulation and evaluation of orodispersible tablet of test masked doxylamine succinate using ion exchange resin. J. King Saud Univ. Sci., v.22, p.229-240, 2010.
SAYEED, A.; MOHIUDDIN, M. Mouth dissolving tablets an overview. Int. Res. Pharm. Biomed. Sci., v.2, n.3, p.959970, 2011.

SHAH, V.; PATEL, S.; RAKESH, K. Formulation and evaluation of mouth dissolving tablets of metoclopramide hydrochloride by direct compression technique. Int. J. Drug Disc. Herbal Res., v.1, n.2, p.100-103, 2011.

SHIRSAND, S.; PARA, M.; RAMANI, R. Novel co-processed superdisintegrants in the design of fast dissolving tablets. Int.J. Pharm. Tech. Res., v.2, n.1, p.223-227, 2010.

SUGIMOTO, M.; NARISAWA, S.; MATSUBARA, K. Development of manufacturing method for rapidly rapidly disintegrating oral tablets using the crystalline transition of amorphous sucrose. Int. J. Pharm., v.320, p.71-78, 2006.

SURESH, S.; SENTHIL, A.; MANIKANDAN, C. Formulation and evaluation of mouth dissolving tablets of amlodipine besylate. Int. Res.J. Pharm., v.2, n.9, p.161-165, 2011.

Received for publication on $02^{\text {nd }}$ July 2012 Accepted for publication on $17^{\text {th }}$ January 2013 